\title{
Analysis of current situation and Countermeasures of information construction in university educational administration system
}

\author{
Haixia Wu \\ Hankou University, Wuhan 430212, China
}

Keywords: Internet, Educational administration management, Informatization.

\begin{abstract}
With the rapid development of Internet technology, the educational administration management in Colleges and universities should keep close to the informatization. In the traditional educational administration system, the disadvantage of information management is becoming increasingly apparent, and it is also a good choice to carry out information construction. Through the research, we can find that there are still many problems in the process of information construction of university educational administration system, and there is still a lot of room for information construction in many universities. This paper will analyze the current situation of the construction of educational management information system in Colleges and universities, on the basis of this, put forward corresponding strategies on how to improve the educational management system of information construction, to further enhance the educational management system of informatization degree and level.
\end{abstract}

\section{Introduction}

Higher education stage, higher education management for higher education activities, higher education quality assurance and promotion are of great significance. The real pressure release of the educational management system in Colleges and universities educational management activities to a great extent, under the background of new curriculum reform, educational administration needs a good innovation, to a certain degree to the informatization construction of the industry is a realistic choice of educational management innovation in Colleges and universities. It also needs to see that under the influence of internal and external factors, educational management system informatization achievements just passable, effectiveness construction of educational management system informatization in Colleges and universities are generally low, therefore, to explore the general path of construction of educational management information system in Colleges and universities is also very necessary[1].

\section{Overview of information construction of university educational administration system}

Educational management system is an important part of the comprehensive management of the educational administration as a general form of internal management in universities, which is usually a management of internal education resources in Colleges and universities, management target is used to integrate the internal resources of education, to ensure the higher education resources allocation and reasonable application. Educational management system informatization construction is a development trend and direction of the teaching management system, which is relying on the Internet and digital information technology, educational management system supporting dynamic process specific educational management. The information construction of university educational administration system not only includes the general application of information technology, but also includes the transformation of the educational management concept of the university. The vigorous development of higher education, the construction of educational information management system to try a lot of colleges and universities, and from the 
overall, educational management system of information construction is not good, a lot of educational management system in the operation has not been affected more information technology, the educational management system operating efficiency is relatively low[2].

The information construction of university educational administration system plays an important role in the management of university educational administration and the development of higher education. Concretely speaking, the information construction of university educational administration system can promote the efficiency of educational administration management. As a component inside the university educational management is more important, which is directly related to the effective allocation of educational resources in Colleges and universities management system informatization construction well, the educational administration department to optimize the allocation of resources for better education, has been fully applied in the educational management system, educational administrative staff working pressure will be decreased gradually. Has improved significantly in the educational management system of informatization level, the overall management of colleges and universities informatization degree, innovation can significantly enhance the higher education also has important significance in the innovation and development in the new period. More importantly, the university educational administration management system informatization construction can produce persistent influence on the educational administration personnel in Colleges and universities, the gradual change in the awareness and attitudes of the educational management information system, also can optimize the internal management system of colleges and universities to help better, thus accelerating the process of educational reform in Colleges and universities[3].

\section{Analysis of the current situation of information construction in university educational administration system}

In the information construction of university educational administration system, the recognition and importance of the information construction of educational administration system will have a direct impact on the achievement of construction. At this stage, many colleges and universities in the educational management system information construction problems on the understanding of limitations, and its educational management system information construction enthusiasm is very low. The college educational administration management informationization construction itself is a need to better co-ordinate system work, but the level of educational administration informatization construction is relatively low, the construction of educational management system informatization in Colleges and universities is difficult to carry out on schedule, system and standardization of the educational management system informatization construction itself is not guaranteed. The information construction of university educational administration system can not be carried on continuously, and the resources investment in the information construction of educational administration system can not be transformed into the result of informatization construction. Once this vicious circle occurs, the views on the construction of the educational administration system will change, and the information system of the educational administration system can not achieve the desired results. In the existing educational management system can play a general management effect, many colleges and universities also lost the enthusiasm of teaching management system information construction[4].

Educational management system of information construction at present lack of flexibility in this situation, lack of flexibility of the educational management system of information construction, the construction of educational information management system cannot fully show the advantages of universities, which is a direct result of a lot of construction of educational management information system in Colleges and universities in the specious, achieved the educational management information system construction achievements later, unable to carry out its subsequent construction of educational management information system. Many colleges and universities habitually educational management system through the information construction of specific purchase educational management information system software, this approach not only leads to educational administration informatization construction funds greater pressure, also makes the method of 
construction of educational management information system for a single pole. Under the lack of the information construction flexibility of the university educational administration system, the efficiency of the information construction of university educational administration will be gradually reduced, and the difficulty of the actual information construction will be gradually increased. In the accelerating process of the new curriculum reform, higher education degree of adjusting the larger and higher frequency, the existing educational management system of informatization construction of scalability is low and lack of flexibility, educational management and higher education activities can not be better coordination between[5].

The construction of educational management information system in Colleges and universities, the information platform of the selection and application of educational management system is more important, the market of various types of educational management information system, there are a large number of different universities, in the construction of the educational administration management information system on the selection and application of Italy to have obvious differences, which also makes the construction of the educational administration management information system is difficult to achieve unity the standard. Higher education resources are a very valuable resource. Under the concept of overall development of higher education, higher education resources need to be shared and spread to some extent. From the macro perspective of education management, the uneven domestic universities educational management system of information platform of quality standards, the educational management system of informatization construction is not unified, the higher education resources are difficult to reach in and the high speed shared mutual exchange of needed products. More seriously, a lot of lack of construction of educational management information system in Colleges and universities once the educational administration information system is scientific and feasible to lower, the normal educational management activities are affected by the negative impact.

Educational management system of information construction for professional talents of higher degree of dependence, but most of the college educational administration management and the lack of information management ability, the construction of educational management information system in Colleges and universities is also facing a severe shortage of talent this fact. That can be analyzed through the development status of the educational management activities, many colleges and universities even the educational management system of informatization construction greatly, but in the actual teaching management, the traditional management methods are still widely used, the application of the construction of educational management system informatization in Colleges and universities is relatively low. The average age of many high school educational administration personnel in the large computer software on the practical ability and willingness to study low, this is a direct result of the construction of educational management system informatization in Colleges and universities can not make substantial progress. Professional talent less construction of educational management system informatization in Colleges and Universities under the educational management system of informatization construction is difficult to clear out the accurate direction in the construction of the educational administration management information system lack of direction, many of its educational management system informatization resources will not translate into the construction of educational management system informatization achievements, and innovation of educational management system of informatization construction of driving force is obviously insufficient[6].

\section{To promote the construction of information system of university educational administration system}

Better the construction of educational management system informatization in Colleges and universities must improve matters related to the degree of attention, with full attention to the construction of the educational administration management information system in universities, a series of educational management system in order to better promote the informatization construction. Suggestions for domestic colleges and universities in the basic direction of information management system on the basis of clear, clear out the construction of the educational 
administration management information system system, and through the educational management system of informatization construction of relevant regulations to carry out the work of informatization construction. The construction of educational management system to enhance the enthusiasm of university informatization is also a continuous process, state finance and local finance needs to be given to educational management system informatization construction to solve the financial support, the leadership and administration is directly responsible for the transition to timely educational management consciousness, which is better for the construction of educational Administration understand and grasp the information system. In the internal construction of the educational management information system is a comprehensive understanding and pay full attention to the situation, construction of educational management information system of the internal environment can be gradually improved, the construction of educational management system informatization in Colleges and universities can steadily.

The achievement of information construction of university educational administration system is closely related to the specific construction methods, and it is also necessary to build a diversified educational administration system. In view of the current educational management system of informatization construction of low extensibility of the existence of the problem, choice and application of information system construction method of educational management is very urgent, the major colleges and universities in the construction of the educational management system in the process of informationization, also need to continue to explore and try to summarize the more experience of the construction of educational management the information system, will be more scientific and feasible educational management information system construction method is introduced and applied to practice. Specifically, universities need to seize the single stage of the educational management system of informatization construction characteristics and targets in the construction of the educational administration management information system, and selectively choose and adopt teaching management system system construction method. In order to evaluate the effectiveness of a series of construction methods, the author makes a re selection and innovation of the information construction method of educational administration system.

The construction of information system of educational administration management needs to be better unified. It is also important to gradually unify the educational administration system and information construction standards. In the educational management system of University, the construction standard of informatization is not the same. Not only the efficiency of higher education resources can not be guaranteed in application, but also the development of educational administration activities in a single university will become very confusing. In order to meet the needs of the construction of educational management information system, management information exchange and resource sharing needs and national education basic database construction, the Ministry of education formulated the "standard" education information management, the information technology education in China towards a healthy and normative development. All colleges and universities in the process of construction of educational information management system also should be better to follow the relevant standards, so that a single educational management system of informatization construction to achieve synchronization with other educational management information system construction. Colleges and universities during the construction of the educational administration management information system also needs to select those universal information management software of the strong, so as to ensure the educational administration information system can keep stable and continuous in operation.

It is necessary to increase the utilization level of professional talents in the construction of information management system of higher educational administration system, and the problem of shortage of talents in informatization construction of educational administration management system in Colleges and universities needs to be solved in time. It is suggested that the domestic universities should set up the educational management system informatization construction concept, and actively carry out educational administration management system, information construction and personnel training. Part of the construction of educational management system informatization in Colleges and universities own talent shortage, companies can consider the introduction of the 
construction of educational management system informatization talents, so as to establish a management system to construction of educational informatization talents. The construction of educational management system informatization in Colleges and universities for larger talent and technology demand, universities also need regular training for professional literacy educational management system informatization construction personnel, through regular training to the relevant personnel to understand the construction of the educational management information system more. In addition, colleges and universities should also run the talent strategy throughout the educational administration management system, and the construction of information technology has always strengthened the scientific degree of the information system construction of the educational administration system. In the case of better educational management system, information construction staff comprehensive literacy, universities should encourage educational management system informatization, construction personnel in the construction of information technology, bold attempt and innovation.

\section{Conclusion}

The information construction of university educational administration system needs more attention and support. The series of problems existing in the information construction of university educational administration system need to be solved in time. Under the new era, the development of higher education is still an unavoidable realistic problem. The pressure of educational reform and innovation is constantly rising. It is especially urgent for the educational administration system of universities to carry out information construction. Educational management system informatization construction should become the norm, especially in many loopholes in the educational management system in many cases, the normalization of university educational administration management system informatization construction to gradually will play out the advantages of informatization construction.

\section{References}

[1]Zhou M W, Tan H W. Preliminary analysis of current situation and countermeasures of informationization construction of our country poduction safety[J]. Opencast Coal Mining Technology, 2005.

[2]Lou S Z. Analysis on the Current Situation of the Construction of Teaching Staff and Countermeasures in Higher Vocational Schools[J]. Vocational \& Technical Education, 2002.

[3]Tian-Long L I. Current Situation and Countermeasures of the Development of Information Technology Teaching Ability of Young University Teachers-—Based on Xi'an Area Colleges and Universities[J]. Modern Educational Technology, 2013.

[4]Feng J. Analysis of the current situation of physical education and the development countermeasures in the countryside of China[J]. Journal of Shandong Institute of Physical Education \& Sports, 2008.

[5]Wei Z L, Ouyang Y. Analysis of Current Situation of Entrepreneurship Education in Chinese Universities and Countermeasures[J]. Theory \& Practice of Education, 2010.

[6]Deng Y, Zhou M. Current Situation Analysis of the Construction of Universities Librarian Morals and Countermeasures[J]. Library Journal, 2008.

Brief introduction of the author:Wu Haixia , Female, Hubei province, December 12th, 1981. Master degree, Lecturer , educational philosophy 